\title{
Structural Studies of 2,6-Diacetyl- and 2,6-Diformylpyridine Bis(thiosemicarbazones)
}

\author{
Christine A. Brown ${ }^{a}$, Werner Kaminsky ${ }^{b}$, Kacey A. Claborn ${ }^{b}$, Karen I. Goldberg $^{b}$ and $^{-}$ \\ Douglas X. West ${ }^{b *}$ \\ ${ }^{a}$ Department of Chemistry, Illinois State University, Normal, IL 61790-4160, USA \\ ${ }^{b}$ Department of Chemistry, University of Washington, Seattle, WA 98195-1700 USA
}

\begin{abstract}
Embora um grande número de estruturas tiosemicarbazonas heterocíclicas tenham aparecido na literatura recentemente, poucas estruturas de bis(tiosemicarbazonas) heterocíclicas e dos seus complexos metálicos foram descritas. Complexos de ferro (II), índio (II), estanho (IV) e bismuto (III) contêm bis(tiosemicarbazonas) coordenadas na forma de ligantes pentadentados $\mathrm{N}_{3} \mathrm{~S}_{2}$, freqüentemente resultando em complexos heptacoordenados. Em comparação, os complexos de zinco (II) são freqüentemente binucleares e contêm as frações tiosemicarbazonas do ligante bis(tiosemicarbazona) coordenadas a dois diferentes centros de zinco. Foi também incluída neste estudo a estrutura do primeiro complexo de níquel (II) que contém um ligante 2,6-diformilpiridina bis(tiosemicarbazona) em uma coordenação incomum.
\end{abstract}

\begin{abstract}
Although a large number of crystal structures of heterocyclic thiosemicarbazones have recently appeared in the literature, few structures of heterocyclic bis(thiosemicarbazones) or their metal complexes have been reported. Complexes of iron(II), indium(III), tin(IV), bismuth(III) involve bis(thiosemicarbazones) coordinating as $\mathrm{N}_{3} \mathrm{~S}_{2}$ pentadentate ligands, often resulting in 7-coordinate complexes. In contrast, complexes with zinc(II) are often binuclear with thiosemicarbazone moieties of a bis(thiosemicarbazone) coordinating to two different zinc centers. Also included in this study is the structure of the first complex with a 2,6-diformylpyridine bis(thiosemicarbazone) ligand, a 4coordinate nickel(II) complex with unusual coordination.
\end{abstract}

Keywords: bis(thiosemicarbazones), 2,6-diacetylpyridine, 2,6-diformylpyridine, crystal structures, metal complexes

\section{Introduction}

Heterocyclic thiosemicarbazones capable of tridentate coordination have been studied extensively, ${ }^{1-5}$ and in recent years many reports involve crystal structures of these thiosemicarbazones and/or their metal complexes. ${ }^{6}$ Also, the structures of bis(thiosemicarbazones) capable of tetradentate coordination and their complexes have been the subject of numerous recent reports. ${ }^{722}$ However, less attention has been given to heterocyclic bis(thiosemicarbazones), Figure 1 (numbering scheme for nitrogens in Figure 1 is used throughout this report, except for the nickel(II) complex), which are capable of higher denticity. This lack of attention is particularly true for those heterocyclic bis(thiosemicarbazones) with substituents

* e-mail: westdx@chem.washington.edu other than $\mathrm{NH}_{2}$ in the $\mathrm{N}$ (4)-position of the thiosemicarbazone moiety. Spectral and biological studies have been carried out on metal complexes of 2,6-diacetylpyridine bis\{N(4)substituted thiosemicarbazones $\}.{ }^{23-25}$ Structural information for a heterocyclic bis $\{\mathrm{N}(4)$-substituted thiosemicarbazone $\}$ has only recently been reported ${ }^{26}$ even though the N(4)substituent(s) in other types of thiosemicarbazones, including bis(thiosemicarbazones), has been shown to significantly affect their biological activity. ${ }^{25}$ The structural study of heterocyclic bis(thiosemicarbazones) and their metal complexes is the subject of this contribution, which is not exhaustive, but representative of this area of chemistry at this writing. Included is the structure of a new nickel(II) complex of a 2,6-diformylpyridine bis $\{\mathrm{N}(4)$-dimethylthiosemicarbazone , [Ni(2,6Fo4DM)]; we believe this is the first complex of a 2,6-diformylpyridine bis(thiosemicarbazone) to be reported. 
<smiles>[R7]/C(=N/NC(=S)N([R5])[R7])c1cccc(/C([R7])=N/N([2H])C(=S)N([R5])[R5])n1</smiles>

Figure 1. Depiction of a heterocyclic bis(thiosemicarbazone)

\section{Structural Studies of the Heterocyclic Bis(thiosemicarbazones)}

Only recently has the crystal structure of a heterocyclic $\mathrm{N}(4)$-substituted bis(thiosemicarbazone) been reported ${ }^{26}$ even though a number of heterocyclic N(4)-substituted thiosemicarbazones have been shown to exist in as many as four different structural forms. ${ }^{27,28}$ Crystals of bright yellow 2,6-diacetylpyridine bis(3-hexyliminylthiosemicarbazide) monohydrate, $\mathrm{H}_{2} 2,6$ Achexim $\cdot \mathrm{H}_{2} \mathrm{O}$, prepared by combining 3-hexyliminylthiosemicarbazide with 2,6-diacetylpyridine in boiling ethanol, were grown from EtOH and crystallized in the orthorhombic $\mathrm{Pbcn}$ space group with 8 molecules in the unit cell. One thiosemicarbazone moiety is in the E conformation with respect to the $\mathrm{C}-\mathrm{N}(2)$ (imine) bond and the $\mathrm{N}(3) \mathrm{H}$ is hydrogen bonding to the hydrate water molecule, Figure 2 . The second thiosemicarbazone moiety has what is normally the $\mathrm{N}(3)$ hydrogen shifted to $\mathrm{N}(2)$ and involved in a bifurcated hydrogen bond with the pyridine nitrogen and thiolato sulfur atoms. This tautomeric form of a thiosemicarbazone moiety with formal charges on $\mathrm{N}(2)$ and $\mathrm{S}$, designated E', has been found for 2-acetylpyridine N(4)dialkyl- and 3-azacyclothiosemicarbazones, ${ }^{27}$ and, more recently, for 2-pyridineformamide N(4)-dialkyl- and 3azacyclothiosemicarbazones. ${ }^{29}$ The two forms of the thiosemicarbazone moiety result in the following

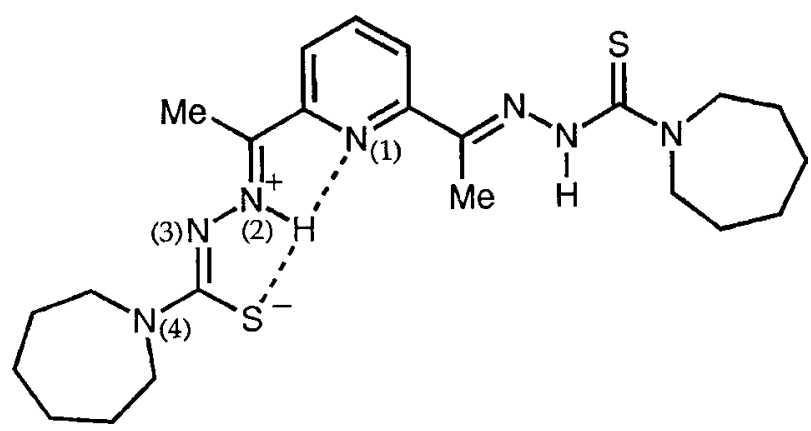

Figure 2. Drawing of $\mathrm{H}_{2} 2,6$ Achexim showing the $\mathrm{E}^{\prime}$ and $\mathrm{E}$ thiosemicarbazone moieties. differences in bond distances: E moiety: C-N(2), 1.313(7) $\AA$; N(2)-N(3), 1.372(7), ̊; C-S, 1.689(7) $\AA$ and E' moiety: $\mathrm{C}-\mathrm{N}(2), 1.291(6) \AA ; \mathrm{N}(2)-\mathrm{N}(3), 1.347(6)$; C-S, 1.716(6) $\mathrm{A}$. The bond angles of these different thiosemicarbazone moieties show even greater variation.

\section{Structural Studies of the Metal Complexes of Heterocyclic Bis(thiosemicarbazones)}

\subsection{Iron(II) complexes}

The first transition metal complex of a heterocyclic bis(thiosemicarbazone) reported was an iron(II) complex, [ $\left.\mathrm{Fe}\left(\mathrm{H}_{2} 2,6 \mathrm{Ac} 4 \mathrm{DH}\right)(\mathrm{NCS})_{2}\right]$, where $\mathrm{H}_{2} 2,6 \mathrm{Ac} 4 \mathrm{DH}$ is $2,6-$ diacetylpyridine bis(thiosemicarbazone).$^{30}$ The complex, which crystallized in the tetragonal $\mathrm{P}_{1} 2_{1} 2$ space group with 4 molecules in the unit cell, is an approximate pentagonal bipyramid with the $\mathrm{N}$-thiocyanato ligands in the apical positions, Figure 3. The NCS groups are linear with $\mathrm{FeNC}$ angles of $178.7(7)^{\circ}$ and interact with the water of crystallization (non-bonding $\mathrm{O} \cdots \mathrm{SCN}$ distance of $3.4 \AA$ ). It should be noted that this complex was obtained by reacting iron(III) with $\mathrm{H}_{2} 2,6 \mathrm{Ac} 4 \mathrm{DH}$, indicating that reduction, more than likely by the bis(thiosemicarbazone), takes place during synthesis. Although a number of other transition metal complexes have been prepared and tested for biological activity, ${ }^{31}$ to our knowledge no other crystal structures have been reported. However, structures of transition metal complexes with 2,6-diacetylpyridine bis(semicarbazone) continue to be an area of study. ${ }^{32}$

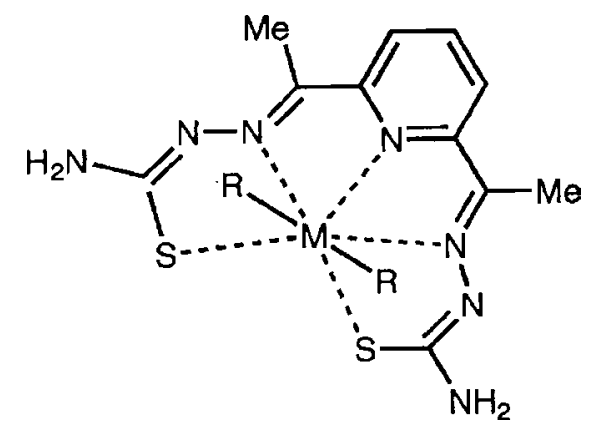

Figure 3. Depiction of the pentagonal bipyramid structure assumed by $\mathrm{Fe}(\mathrm{II}), \mathrm{In}(\mathrm{III}), \mathrm{Sn}(\mathrm{IV})$ and mononuclear $\mathrm{Zn}$ (II) 7-coordinate complexes.

\subsection{Indium(III) complexes}

Two complexes involving the monoanion \{i.e., one of the thiosemicarbazone moieties has lost $\mathrm{N}(3) \underline{\mathrm{H}}$ \} of 2,6diacetylpyridine bis(thiosemicarbazone), $\mathrm{H}_{2} 2,6 \mathrm{Ac} 4 \mathrm{DH}$, are included in a recent article. ${ }^{33}$ Crystals of $\left[\mathrm{In}\left(\mathrm{H} 2,6 \mathrm{Ac}^{2} \mathrm{DH}\right) \mathrm{Cl}_{2}\right] \cdot \mathrm{DMSO}$, which is sparingly soluble 
in most solvents, were obtained by dissolution in boiling dimethyl sulfoxide followed by cooling the solution at $10 \%$ h. The complex has monoanionic H2,6Ac4DH coordinating as a pentadentate ligand via the pyridine nitrogen, two imine nitrogen atoms and the thione and thiolato sulfur atoms with chloro ligands in the apical positions of an approximate pentagonal bipyramid, Figure 3. This complex provides a comparison of two different thiosemicarbazone moieties in the same complex. It should be noted that there are several complexes with heterocyclic tridentate thiosemicarbazone ligands that have two forms of different charge attached to the same metal, ${ }^{34,35}$ as well as inequivalent coordination of the same form. ${ }^{36}$ Listed in Table 1 are selected bond distances for the two forms, and there is considerable difference. Bonds to indium(III) for the anionic thiosemicarbazone moiety are shorter than the analogous bonds of the neutral moiety. The thione C-S bond in the neutral moiety remains a formal double bond making it shorter than the C-S bond of the anionic moiety, and the N(3)-C bond (Figure1) which formally becomes a double bond in the anionic moiety, is longer in the neutral moiety. The In-Npy bond is $2.330(5) \AA$, the apical chloro distances show a small difference, 2.497(2) and 2.535(2) $\AA$, and the Cl-In-Cl angle is $166.02(5)^{\circ}$ indicating significant distortion from a regular stereochemistry.

Table 1. Selected bond distances $(\AA)$ of the anionic and neutral thiosemicarbazone moieties in $\left[\operatorname{In}(\mathrm{H} 2,6 \mathrm{Ac} 4 \mathrm{DH}) \mathrm{Cl}_{2}\right]$.

\begin{tabular}{lll}
\hline Bond & Anionic moiety $(\AA)$ & Neutral moiety $(\AA)$ \\
In-S & $2.572(2)$ & $2.670(2)$ \\
In-N(2)(imine) & $2.335(5)$ & $2.458(5)$ \\
C-S & $1.743(6)$ & $1.680(6)$ \\
C-N(2)(imine) & $1.322(8)$ & $1.281(8)$ \\
N(3)-C(S) & $1.322(8)$ & $1.361(8)$ \\
\hline
\end{tabular}

An interesting second complex with the monoanionic bis(thiosemicarbazone) of 2,6-diacetylpyridine was prepared with $\mathrm{In}\left(\mathrm{NO}_{3}\right)_{3} \cdot 5 \mathrm{H}_{2} \mathrm{O} \cdot{ }^{33}$ With monoanionic
$\mathrm{H} 2,6 \mathrm{Ac} 4 \mathrm{DH}$ coordinating as a planar pentadentate ligand as in $\left[\operatorname{In}(\mathrm{H} 2,6 \mathrm{Ac} 4 \mathrm{DH}) \mathrm{Cl}_{2}\right],\left\{\mathrm{O}[\mathrm{In}(\mathrm{H} 2,6 \mathrm{Ac} 4 \mathrm{DH})(\mathrm{OH})]_{2}\right\}$ - $5 \mathrm{MeOH}$ consists of two In(III) centers bridged by an oxido ligand and hydroxo ligands at the terminal, apical positions. The two In(III) centers, bridged by the oxido ligand, are like the center shown in Figure 3, and are rotated ca. $180^{\circ}$ to each other, the In-O bonds are about $0.1 \AA$ shorter than the In-OH bonds and the In-O-In angle is $179.8(5)^{\circ}$. It was not possible to locate all of the hydrogens in the final Fourier map, but the differences in bond distances in the anionic and neutral thiosemicarbazone moieties are similar to those of $\left[\mathrm{In}(\mathrm{H} 2,6 \mathrm{Ac} 4 \mathrm{DH}) \mathrm{Cl}_{2}\right]$.

\section{$3.3 \operatorname{Tin}(I V)$ complexes}

Complexes of the unsubstituted 2,6-diacetylpyridine bis(thiosemicarbazone), $\mathrm{H}_{2} 2,6 \mathrm{Ac} 4 \mathrm{DH}$, have received considerable attention and number of 7-coordinate tin(IV) complexes have been reported. The hydrochloride salt of $\mathrm{H}_{2} 2,6 \mathrm{Ac} 4 \mathrm{DH}$ was dissolved in dry $\mathrm{MeOH}$ and the various $\mathrm{Sn}(\mathrm{IV})$ species also dissolved in $\mathrm{MeOH}$ were added and the mixtures refluxed for an hour. Neutral complexes with the dianionic bis(thiosemicarbazone) resulted on loss of $\mathrm{HCl}$ and cationic complexes with the monoanionic thiosemicarbazone/thiosemicarbazonato ligand $\{$ i.e., only one of the moieties loses $\mathrm{N}(3) \mathrm{H}\}$ are formed and 2,6Ac4DH and H2,6Ac4DH both coordinate about the $\mathrm{Sn}$ in an approximate pentagonal plane. Two apical positions are occupied by monodentate aryl, alkyl or halo ligands and raise the coordination number to seven for approximate pentagonal bipyramids. The bond distances involving tin(IV) and the bis(thiosemicarbazone) ligands are listed in Table 2 for the complexes discussed below.

\subsection{Neutral tin(IV) complexes}

$\left[\mathrm{Sn}(2,6 \mathrm{Ac} 4 \mathrm{DH}) \mathrm{Ph}_{2}\right] \cdot 2 \mathrm{DMF}$ crystallized in the $\mathrm{P} 2_{1} / \mathrm{n}$ space group with $Z=4$ and solved to a very good $R$ value

Table 2. Selected bond distances ( $\AA$ ) for pentagonal bipyramid tin(IV) complexes of 2,6-diacetylpyridine bis(thiosemicarbazones).

\begin{tabular}{|c|c|c|c|c|}
\hline Compound & Sn-Npy & Sn-N2 & Sn-S & Ref \\
\hline Neutral & & & & \\
\hline$\left[\mathrm{Sn}(2,6 \mathrm{Ac} 4 \mathrm{DH}) \mathrm{Ph}_{2}\right]$ & $2.368(3)$ & $\begin{array}{l}2.427(4) \\
2.421(4)\end{array}$ & $\begin{array}{l}2.593(1) \\
2.603(1)\end{array}$ & 37 \\
\hline $\begin{array}{l}{\left[\mathrm{Sn}(2,6 \text { Achexim }) \mathrm{Bu}_{2}\right]^{\mathrm{a}}} \\
\text { Cations }\end{array}$ & $2.415(6)$ & $2.437(5)$ & $2.6924(16)$ & 26 \\
\hline$[\mathrm{Sn}(\mathrm{H} 2,6 \mathrm{Ac} 4 \mathrm{DH}) \mathrm{ClMe}] \mathrm{Cl}$ & $2.238(6)$ & $\begin{array}{l}2.288(6)^{b} \\
2.430(6)^{c}\end{array}$ & $\begin{array}{l}2.527(2)^{\mathrm{b}} \\
2.633(2)^{\mathrm{c}}\end{array}$ & 38 \\
\hline$\left[\mathrm{Sn}(\mathrm{H} 2,6 \mathrm{Ac} 4 \mathrm{DH}) \mathrm{Ph}_{2}\right] \mathrm{Cl}$ & $2.348(4)$ & $\begin{array}{l}2.353(4)^{b} \\
2.491(4)^{c}\end{array}$ & $\begin{array}{l}2.592(1)^{\mathrm{b}} \\
2.703(1)^{\mathrm{c}}\end{array}$ & 39 \\
\hline
\end{tabular}

a) symmetrical, 2,6Achexim is the dianion of 2,6-diacetylpyridine 3-hexamethyleneiminylthiosemicarbazone; b) anionic moiety; c) neutral moiety. 
of $0.035 .{ }^{37}$ The following summarizes the distortion from regular stereochemistry: the $\mathrm{Sn}(\mathrm{IV})$ center is displaced from the basal plane (average deviation is $0.027 \AA$ ) by $0.021(1)$ $\AA$, the C-Sn-C angle is $166.9(2)^{\circ}$ and the mean planes of the phenyl rings are $28.8(2)^{\circ}$ from each other. Hydrogen bonding interactions by $\mathrm{N}(4) \underline{\mathrm{H}}_{2}$ to the DMF oxygen have the following parameters: $\mathrm{N}-\mathrm{H} \cdots \mathrm{O}, 2.847(6) \AA \mathrm{A}^{\circ} \mathrm{H} \cdots \mathrm{O}$, 1.92(9) $\AA$, and $\angle \mathrm{N}-\mathrm{H} \cdots \mathrm{O}, 158.9(8)^{\circ}$ for one interaction and $\mathrm{N}-\mathrm{H} \cdots \mathrm{O}, 2.867(7) \AA$; $\mathrm{H} \cdots \mathrm{O}, 1.986(5) \AA$, and $\angle \mathrm{N}$ $\mathrm{H} \cdots \mathrm{O}, 153.7(6)^{\circ}$ for the other.

Crystals of the 7-coordinate neutral complex, $\left[\mathrm{Sn}(2,6 \mathrm{Achexim}) \mathrm{Bu}_{2}\right](2,6$ Achexim is the dianion of 2,6diacetylpyridine 3-hexamethyleneiminylthiosemicarbazone), ${ }^{26}$ were grown by slow evaporation of $\mathrm{EtOH}$, and the structure is again an approximate pentagonal bipyramid. The structure was solved as orthorhombic Pnma symmetry group with $\mathrm{Z}=4$. The axial butyl groups contribute to the distortion since the C-Sn-C angle is 171.6(4) ${ }^{\circ}$. The tin(IV) is 0.008(3) $\AA$ out of the plane of the pentagonal ring, S$\mathrm{N}(2)-\mathrm{Npy}-\mathrm{N}(2)-\mathrm{S}$ (mean deviation $0.0751 \AA$ ). Coordination to the tin(IV) center by the imine nitrogen and the thiolato sulfur lengthens $\mathrm{N}(2)-\mathrm{C}$ to $1.331(7) \AA$, as well as $\mathrm{S}-\mathrm{C}$ to 1.746(7) $\AA$, from an average of 1.302(7) $\AA$ and 1.703(7) $\AA$, respectively, in $\mathrm{H}_{2} 2,6$ Achexim $\mathrm{H}_{2} \mathrm{O}$. One of the butyl groups shows considerable disorder and contributes to the relatively high R-value, 0.0540 .

\subsection{Cationic tin(IV) complexes}

Crystals of $[\mathrm{Sn}(\mathrm{H} 2,6 \mathrm{Ac} 4 \mathrm{DH})(\mathrm{Me}) \mathrm{Cl}] \mathrm{Cl} \cdot \mathrm{MeOH}^{38}$ were acquired by slow evaporation of the preparative solution, and the structure was solved to be monoclinic $\mathrm{P} 2 / \mathrm{c}$ with $\mathrm{Z}=4$. With the monoanionic ligand this is another complex that provides an interesting contrast between its two thiosemicarbazone moieties, as well as tin(IV) complexes with dianionic 2,6Ac4DH. Tin(IV)-ligand bond distances, Table 2, are listed together for the two moieties to allow easy comparison. Also included in this article is the bis(semicarbazone) complex, [ $\mathrm{Sn}(2,6 \mathrm{AcO} 4 \mathrm{DH})(\mathrm{Me}) \mathrm{Cl}]$, which has the following bond distances: $\mathrm{Sn}-\mathrm{N}(\mathrm{Py})=$ 2.262(2) $\AA$ and Sn-N(im) = 2.284(7) and 2.252(7) $\mathrm{A}$.

Yellow $\left[\mathrm{Sn}(\mathrm{H} 2,6 \mathrm{Ac} 4 \mathrm{DH}) \mathrm{Ph}_{2}\right] \mathrm{Cl}$ crystallizes from dry methanol in the $\mathrm{P} 2 \mathrm{l} / \mathrm{n}$ symmetry group with four formula units per unit cell. ${ }^{39}$ The anionic pentadentate ligand coordinates as discussed above and the bond distances are listed in Table 2. The Sn-C(phenyl) distances are 2.163(4) and 2.170(4) $\AA$ and the two phenyl rings form an angle between their mean planes of $44.4(3)^{\circ}$, which is significantly larger than found for $\left[\mathrm{Sn}(2,6 \mathrm{Ac} 4 \mathrm{DH}) \mathrm{Ph}_{2}\right]^{37}$ discussed previously. The thiolato C-S bond distance, 1.731(5) $\AA$, is significantly longer than the thione C-S distance, 1.694(6) $\AA$, and the $\mathrm{C}-\mathrm{N}(2)$ distance (anionic moiety) $=1.346(6) \AA$ compared to the neutral moiety's 1.290(6) $\AA$, again indicating significant differences between the two moieties. The chloride counterion interacts with the complex through hydrogen bonds, the remaining $\mathrm{N}(3) \mathrm{H}$ forming the strongest interaction: $\mathrm{N}$ $\mathrm{H} \cdots \mathrm{Cl}, 3.071(5) \AA ; \mathrm{H} \cdots \mathrm{Cl}, 2.24(7) \AA ; \angle \mathrm{NH} \cdots \mathrm{Cl}$, $157(6)^{\circ}$. One hydrogen attached to $\mathrm{N}(4)$ interacts more weakly with the chloride counterion: : $\mathrm{N}-\mathrm{H} \cdots \mathrm{Cl}, 3.216(7)$ $\AA ; \mathrm{H} \cdots \mathrm{Cl}, 2.44(7) \AA ; \angle \mathrm{NH} \cdots \mathrm{Cl}, 150(6)^{\circ}$ and the other $\mathrm{N}(4)$ hydrogen, as well as the anionic moiety's $\mathrm{N}(4) \mathrm{H}_{2}$, interact with chlorides of other formula units.

\subsection{Bismuth(III) complexes}

Reaction between $\mathrm{BiCl}_{3}$ and $\mathrm{H}_{2} 2,6 \mathrm{Ac} 4 \mathrm{DH}$ in acetone, evaporation to dryness followed by dissolution of the powder in DMSO, addition of excess $\mathrm{NaN}_{3}$ and slow evaporation of this solution produced red crystals of $\left[\mathrm{Bi}(2,6 \mathrm{Ac} 4 \mathrm{DH})\left(\mathrm{N}_{3}\right)\right] \cdot 0.5 \mathrm{DMSO}, \mathrm{P} 2_{1} / \mathrm{n}$ and $\mathrm{Z}=2 .{ }^{40}$ $2,6 \mathrm{Ac} 4 \mathrm{DH}$ coordinates via the usual pyridine nitrogen, imine nitrogen atoms and thiolato sulfur atoms and the essentially linear azido ligand, $\angle \mathrm{N}-\mathrm{N}-\mathrm{N}=178(3)^{\circ}$, brings the coordination number to 6 resulting in an approximate pentagonal pyramid structure. The azido ligand coordinates in the expected fashion with $\angle \mathrm{Bi}-\mathrm{N}-\mathrm{N}=121(1)^{\circ}$. $\mathrm{Bi}-$ $\mathrm{S}$ bond distances are 2.717(8) and 2.685(7) $\AA, \mathrm{Bi}-\mathrm{N}(2)=$ 2.58(2) and 2.46(2) $\AA$ and Bi-N(1) is listed as 2.44(2) $\AA$ although it would seem based on other complexes of 2,6Ac4DH that this value should be longer $\{$ e.g. $2.58(2) \AA$. The Bi-N(azido) distance is 2.25(2) $\AA$. The packing of the molecules is by means of contacts with the other terminal nitrogen of the azido ligand and the unoccupied apical position on the $\mathrm{Bi}$ of an adjacent molecule.

\subsection{Zinc(II) complexes}

Like zinc complexes of the 2,6-diacetylpyridine bis(semicarbazone), ${ }^{41}$ heterocyclic bis(thiosemicarbazone) complexes with zinc show greater variation in their mode of coordination than the previously discussed complexes. For example, an early article ${ }^{42}$ contains structures of both mononuclear and binuclear zinc complexes with two different modifications of the latter.

\subsection{Mononuclear zinc(II) complexes}

$\left[\mathrm{Zn}\left(\mathrm{H}_{2} 2,6 \mathrm{Ac} 4 \mathrm{DH}\right)\left(\mathrm{H}_{2} \mathrm{O}\right)_{2}\right]\left(\mathrm{NO}_{3}\right)_{2}$, an approximate pentagonal bipyramid complex with a neutral bis(thiosemicarbazone) ligand, was obtained from methanol-nitric acid solution and crystallizes in the 
monoclinic Cc space group with four molecules in the unit cell. ${ }^{42}$ The neutral pentadentate ligand is approximately planar; the $\mathrm{N}(2)$ nitrogens show the greatest deviation from planarity. Interestingly, the average $\mathrm{Zn}-\mathrm{S}$ distance, 2.580(3) $\AA$, is shorter than the Fe-S distance, $2.639(4) \AA$, of $\left[\mathrm{Fe}\left(\mathrm{H}_{2} 2,6 \mathrm{Ac} 4 \mathrm{DH}\right)(\mathrm{NCS})_{2}\right] .^{30}$

\subsection{Binuclear zinc(II) complexes}

Two binuclear zinc(II) complexes were reported in the same article. ${ }^{42}$ One of the complexes, $[\mathrm{Zn}(2,6 \mathrm{Ac} 4 \mathrm{DH})]_{2}$ - $\mathrm{MeOH} \cdot 2 \mathrm{DMF}$, features two zinc centers reported to have distorted octahedral symmetry, Figure 4a. This complex crystallizes from DMF in the monoclinic $\mathrm{C} 2 / \mathrm{c}$ space group with four molecules in the unit cell, but only half a $[\mathrm{Zn}(2,6 \mathrm{Ac} 4 \mathrm{DH})]_{2}$ in the asymmetric unit with the other half related to it by a crystallographic two-fold axis. Each zinc atom in the binuclear complex is coordinated to two sulfur and two nitrogen $\{$ i.e., $\mathrm{N}(2)\}$ atoms from two different $2,6 \mathrm{Ac} 4 \mathrm{DH}$ ligands. The two pyridine nitrogens have weak interactions that "bridge" the zinc centers of the binuclear unit to bring the coordination number to six. The pyridine nitrogens are closer to one zinc, 2.571(4) $\AA$, than the other, 2.705(5) $\AA$ and the $\mathrm{Zn}-\mathrm{N}-\mathrm{Zn}$ angle is $94.2(2)^{\circ}$ with a $\mathrm{Zn}-$ $\mathrm{Zn}$ separation of 3.866(1) A. The other Zn-ligand bond distances are listed in Table 3, and it appears based on the other complexes that "coordination" of the pyridine nitrogens could be described as a weak interaction and that the two zinc(II) centers could be considered as 5coordinate, or even 4-coordinate. The S-Zn-S angle is $110.75(7)^{\circ}$ suggesting tetrahedral symmetry, but the $\mathrm{N}(2)$ $\mathrm{Zn}-\mathrm{N}(2)$ angle is $152.5(1)^{\circ}$, more consistent with distorted octahedral or trigonal bipyramid symmetry (i.e., $\mathrm{N}(2)$ 's in apical positions). This same complex was reported by another group with essentially the same structural characteristics a few years later. ${ }^{43}$
A second binuclear complex, $[\mathrm{Zn}(2,6 \mathrm{Ac} 4 \mathrm{DH})]_{2}$ $\cdot \mathrm{MeOH} \cdot \mathrm{H}_{2} \mathrm{O}$, is a structural isomer of the aforementioned $[\mathrm{Zn}(2,6 \mathrm{Ac} 4 \mathrm{DH})]_{2} \cdot \mathrm{MeOH} 2 \mathrm{DMF}$ in terms of the zinc centers. ${ }^{42}$ One zinc atom is coordinated to two sulfur and four nitrogen donors \{i.e., two $\mathrm{N}(2)$ atoms and two inequivalently coordinated pyridine nitrogen atoms, Table $3\}$ in a distorted octahedral arrangement, Figure $4 \mathrm{~b}$. The second zinc(II) is coordinated to two sulfur and two imine nitrogen donors in a distorted tetrahedral arrangement $\{$ i.e., the pyridine nitrogens are 2.737(9) and 2.909(9) ^ from

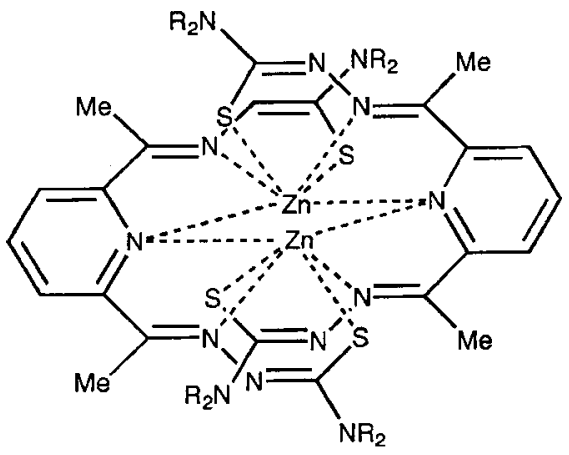

a

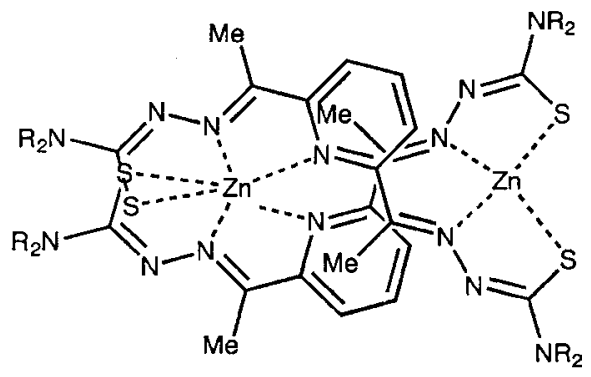

$\mathrm{b}$

Figure 4. Attempt to show the bonding in binuclear $\mathrm{Zn}(\mathrm{II})$ complexes; a) "octahedral-octahedral" and b) "octahedraltetrahedral".

Table 3. Selected bond distances $(\AA)$ for zinc complexes of 2,6-diacetylpyridine bis(thiosemicarbazones). ${ }^{a}$

\begin{tabular}{|c|c|c|c|c|}
\hline Compound & Zn-Npy & $\mathrm{Zn}-\mathrm{N}(2)$ & $\mathrm{Zn}-\mathrm{S}$ & Ref \\
\hline$\left[\mathrm{Zn}\left(\mathrm{H}_{2} 2,6 \mathrm{Ac} 4 \mathrm{DH}\right)\left(\mathrm{H}_{2} \mathrm{O}\right)_{2}\right]\left(\mathrm{NO}_{3}\right)_{2}$ & $2.213(7)$ & $2.346(9)$ & $2.580(3)$ & 42 \\
\hline \multirow[t]{2}{*}[\mathrm{Zn}(2,6\mathrm{Ac}4\mathrm{DH})]{$_{2} \mathrm{MeOH} 2 \mathrm{DMF}$} & $2.571(4)$ & $2.099(4)$ & $2.358(2)$ & 42 \\
\hline & $2.705(5)$ & & & \\
\hline \multirow[t]{2}{*}[\mathrm{Zn}(2,6\mathrm{Ac}4\mathrm{DH})]{$_{2} \cdot 2 \mathrm{DMF}$} & $2.574(4)$ & & $2.360(2)$ & 43 \\
\hline & $2.707(4)$ & & & \\
\hline \multirow[t]{2}{*}[\mathrm{Zn}(2,6\mathrm{Ac}4\mathrm{DH})]{$_{2} \cdot \mathrm{MeOH} \cdot \mathrm{H}_{2} \mathrm{O}$} & $2.266(9)$ & 2.11(1) & $2.420(4)$ & 42 \\
\hline & $2.46(1)$ & & & \\
\hline "tetrahedral Zn" & & $2.07(1)$ & $2.322(3)$ & \\
\hline$[\mathrm{Zn}(2,6 \mathrm{Ac} 4 \mathrm{DM})]_{2}^{\mathrm{b}}$ & $2.476(6)$ & $2.029(6)$ & $2.509(2)$ & 44 \\
\hline "tetrahedral Zn" & & $1.989(6)$ & $2.338(3)$ & \\
\hline$[\mathrm{Zn}(2,6 \text { Achexim })]_{2}^{\mathrm{c}}$ & & $2.052(6)$ & $2.358(2)$ & 26 \\
\hline
\end{tabular}

a)Averages are listed when the coordination is considered equivalent; b)The two bonds are identical for both centers and 2,6Ac4DM is the dianion of 2,6-diacetylpyridine bis(N4-dimethylthiosemicarbazone); c)2,6Achexim is the dianion of 2,6-diacetylpyridine 3hexamethyleneiminylthiosemicarbazone. 
this zinc center $\}$. $[\mathrm{Zn}(2,6 \mathrm{Ac} 4 \mathrm{DH})]_{2} \cdot \mathrm{MeOH} \cdot \mathrm{H}_{2} \mathrm{O}$ crystallizes from methanol in the triclinic $\mathrm{P}-1$ space group with two molecules per unit cell and has a rather large $\mathrm{R}$ value of 0.070 . The $\mathrm{N}(2)-\mathrm{Zn}-\mathrm{N}(2)$ angle for the "octahedral zinc(II)" is $169.5(4)^{\circ}$, which is larger than the analogous angle, 154.61 $(18)^{\circ}$, found for octahedral bis(2-pyridineformamide 3-piperidylthiosemicarbazonato)zinc(II) ${ }^{29}$ The tetrahedral zinc(II) center has S-Zn-S and N(2)-Zn-N(2) angles of $118.3(2)$ and $140.8(4)^{\circ}$, which are not very different from the "octahedral" center of $[\mathrm{Zn}(2,6 \mathrm{Ac} 4 \mathrm{DH})]_{2}$ $\cdot \mathrm{MeOH} \cdot 2 \mathrm{DMF}$. The other two angles that involve the $\mathrm{N}(2)-\mathrm{N}(3)-\mathrm{C}-\mathrm{S}-\mathrm{Zn}$ chelate rings, the $\mathrm{N}(2)-\mathrm{Zn}-\mathrm{S}$ angles, are 111.6(4) and $120.8(3)^{\circ}$.

[Zn(2,6Achexim) $]_{2}$ was prepared by refluxing 1:1 (by mole) mixture of $\mathrm{H}_{2} 2,6$ Achexim with zinc(II) acetate in absolute ethanol. The bonding in $[\mathrm{Zn}(2,6 \text { Achexim })]_{2}$, which crystallized from ethanol in the $\mathrm{P} 2 / \mathrm{c}$ symmetry group with $\mathrm{Z}=4$, is described as distorted tetrahedral stereochemistry about the two zinc centers, which are equivalent. ${ }^{26}$ The bond distances for the $\mathrm{Zn}$-ligand bonds are listed in Table 3 and the structure appears to be similar to $[\mathrm{Zn}(2,6 \mathrm{Ac} 4 \mathrm{DH})]_{2} \cdot \mathrm{MeOH} \cdot 2 \mathrm{DMF},{ }^{42}$ which was considered to have octahedral coordination. A comparison of the bond angles for the two complexes shows the following: $[\mathrm{Zn}(2,6 \mathrm{Ac} 4 \mathrm{DH})]_{2} \cdot \mathrm{MeOH} \cdot 2 \mathrm{DMF}, \mathrm{S}-\mathrm{Zn}-\mathrm{S}, 110.75(7)^{\mathrm{o}}$; N(2)-

Table 4. Crystal data and structure refinement for [Ni(2,6Fo4DM)].

\begin{tabular}{|c|c|}
\hline Empirical formula & $\mathrm{C}_{13} \mathrm{H}_{17} \mathrm{~N}_{7} \mathrm{NiS}_{2}$ \\
\hline $\begin{array}{l}\text { Color, habit } \\
\text { Formula weight }\end{array}$ & $\begin{array}{l}394.17 \\
\end{array}$ \\
\hline Temperature, $\mathrm{K}$ & $293(2)$ \\
\hline Crystal system & triclinic \\
\hline Space group & P-1 (\#2) \\
\hline$a, \AA$ & $7.4330(8)$ \\
\hline$b, \AA$ & $10.4310(13)$ \\
\hline$c, \AA$ & $10.7280(13)$ \\
\hline$\alpha,{ }^{\circ}$ & $88.480(5)$ \\
\hline$\beta, \circ$ & $85.205(6)$ \\
\hline$\gamma,{ }^{\circ}$ & $79.787(7)$ \\
\hline Volume, $\AA^{3}$ & $815.68(17)$ \\
\hline $\mathrm{Z}$ & 2 \\
\hline Density, $\mathrm{Mg} / \mathrm{m}^{3}$ & 1.605 \\
\hline Absorption coefficient, $\mathrm{mm}^{-1}$ & 1.454 \\
\hline Crystal size, $\mathrm{mm}$ & $0.17 \times 0.10 \times 0.05$ \\
\hline$\theta$ range for data collection, ${ }^{\circ}$ & $3.51-24.71$ \\
\hline Index ranges & $\begin{array}{l}-8 \leq \mathrm{h} \leq 8 ;-12 \leq \mathrm{k} \leq 12 ; \\
-12 \leq 1 \leq 12\end{array}$ \\
\hline Reflections collected & 4719 \\
\hline Unique reflections & $2732\left[\mathrm{R}_{\mathrm{int}}=0.0435\right]$ \\
\hline Absorption correction & HKL-SCALEPACK \\
\hline Max. / min. transmission & $0.9308 / 0.7901$ \\
\hline Data / restraints / parameters & $2732 / 0 / 233$ \\
\hline Goodness-of-fit on $\mathrm{F}^{2}$ & 0.901 \\
\hline Final $\mathrm{R}$ indices $[\mathrm{I}>2 \sigma(1)]$ & $\mathrm{R}_{1}=0.0380 \mathrm{wR}_{2}=0.0728$ \\
\hline $\mathrm{R}$ indices (all data) & $\mathrm{R}_{1}=0.0784 \mathrm{wR}_{2}^{2}=0.0830$ \\
\hline Largest difference peak/hole, $\mathrm{e}^{-3}$ & 0.258 and -0.262 \\
\hline
\end{tabular}

$\mathrm{Zn}-\mathrm{N}(2), 152.5(1)^{\circ}$ and $\left[\mathrm{Zn}(2,6 \text { Achexim) }]_{2}, \mathrm{~S}-\mathrm{Zn}-\mathrm{S}\right.$, $114.6(1)^{\circ} ; \mathrm{N}(2)-\mathrm{Zn}-\mathrm{N}(2), 159.2(2)^{\circ}$. The Zn-S bond distances are the same in the two complexes, but $\mathrm{Zn}-\mathrm{N}(2)$ is shorter in $[\mathrm{Zn}(2,6 \mathrm{Achexim})]_{2}$, and is even shorter than found for the tetrahedral zinc in $[\mathrm{Zn}(2,6 \mathrm{Ac} 4 \mathrm{DH})]_{2} \cdot \mathrm{MeOH} \cdot \mathrm{H}_{2} \mathrm{O} \cdot{ }^{42}$

The crystal structure of a second binuclear zinc complex with a heterocyclic bis $\{\mathrm{N}(4)$-substituted thiosemicarbazone $\},[\mathrm{Zn}(\mathrm{Ac} 4 \mathrm{DM})]_{2} \cdot 1 / 2 \mathrm{MeCN}$, where Ac4DM is the dianion of 2,6-diacetylpyridine bis(N4dimethylthiosemicarbazone), has recently appeared. ${ }^{44}$ This complex was prepared by electrochemical oxidation of metallic zinc in an acetonitrile solution of $\mathrm{H}_{2} 2,6 \mathrm{Ac} 4 \mathrm{DM}$. The symmetry group is $\mathrm{C} 2 / \mathrm{c}$ with 4 molecules in the unit cell. Like $[\mathrm{Zn}(2,6 \mathrm{Ac} 4 \mathrm{DH})]_{2} \cdot \mathrm{MeOH} \cdot \mathrm{H}_{2} \mathrm{O}^{42}$ this complex has octahedral and tetrahedral zinc centers, but both are much more symmetrical for $[\mathrm{Zn}(\mathrm{Ac} 4 \mathrm{DM})]_{2}$, Table 3 . Consistent with more regular octahedral coordination is the $\mathrm{N}(2)-\mathrm{Zn}-\mathrm{N}(2)$ angle, $176.6(4)^{\circ}$, and the two bond distances for Zn-Npy, Zn-N(2) and Zn-S are identical. Similarly, the $\mathrm{Zn}-\mathrm{N}(2)$ and $\mathrm{Zn}-\mathrm{S}$ bond distances are equivalent for the tetrahedral symmetry. The S-Zn-S and $\mathrm{N}(2)-\mathrm{Zn}-\mathrm{N}(2)$ bond angles are 99.93(13) and 135.2(4) respectively.

\subsection{Nickel(II) complexes}

We include here the first example of a metal complex with the dianion of a 2,6-diformylpyridine bis $\{\mathrm{N}(4)$ dimethylthiosemicarbazone \} ligand, [Ni(2,6Fo4DM)], Figure 5 (the numbers without parentheses used in this section are those of Figure 5 and Table 5). This complex was prepared by reacting equimolar amounts of nickel(II) acetate and 2,6-diformylpyridine N(4)-dimethylthiosemicarbazone in refluxing ethanol. The crystal, grown from a 1:1 by volume mixture of methanol and acetonitrile, was mounted on a glass fiber and used for data collection on a Nonius CCD automatic diffractometer, MoKa $(1=0.71073 \AA$ A). The structure was solved with direct methods and missing atoms were found by difference-Fourier synthesis. All nonhydrogen atoms were refined with anisotropic temperature factors and the hydrogens, except for the methyl hydrogens, were found on the difference map and refined isotropically. The methyl hydrogens were fixed at $\mathrm{d}=0.96 \AA$, allowed to ride on the $\mathrm{C}$ atoms and assigned fixed isotropic temperature factor, $U=0.05 \AA^{2}$. Refinement of the structures was made by full-matrix least-squares on $\mathrm{F}^{2}$. Scattering factors are from Wassmaire and Kirfel, ${ }^{45}$ calculations were done by maXus, version $2.0^{46}$ and graphics are Platon for Windows. ${ }^{47}$

Crystallographic and refinement data are shown in Table 4 for $[\mathrm{Ni}(2,6 \mathrm{Fo} 4 \mathrm{DM}]$. Figure 5 shows that the two 
Table 5. Selected bond distances $(\AA)$ and angles $\left({ }^{\circ}\right)$ for [Ni(2,6Fo4DM)].

\begin{tabular}{|c|c|c|c|}
\hline \multicolumn{4}{|l|}{ Bond distance } \\
\hline $\mathrm{Ni}(1)-\mathrm{N}(1)$ & $1.876(3)$ & & \\
\hline $\mathrm{Ni}(1)-\mathrm{N}(2)$ & $1.849(3)$ & $\mathrm{Ni}(1)-\mathrm{N}(13)$ & $1.843(3)$ \\
\hline $\mathrm{Ni}(1)-\mathrm{S}(1)$ & $2.1827(9)$ & & \\
\hline $\mathrm{N}(1)-\mathrm{C}(2)$ & $1.368(4)$ & $\mathrm{N}(1)-\mathrm{C}(6)$ & $1.343(4)$ \\
\hline$C(2)-C(7)$ & $1.436(5)$ & $\mathrm{C}(6)-\mathrm{C}(17)$ & $1.420(5)$ \\
\hline $\mathrm{C}(7)-\mathrm{N}(2)$ & $1.302(4)$ & $\mathrm{C}(17)-\mathrm{N}(12)$ & $1.302(4)$ \\
\hline $\mathrm{N}(2)-\mathrm{N}(3)$ & $1.376(3)$ & $\mathrm{N}(12)-\mathrm{N}(13)$ & $1.338(3)$ \\
\hline $\mathrm{N}(3)-\mathrm{C}(8)$ & $1.319(4)$ & $\mathrm{N}(13)-\mathrm{C}(18)$ & $1.425(4)$ \\
\hline $\mathrm{C}(8)-\mathrm{S}(1)$ & $1.747(3)$ & $\mathrm{C}(18)-\mathrm{S}(2)$ & $1.669(4)$ \\
\hline $\mathrm{C}(8)-\mathrm{N}(4)$ & $1.343(4)$ & $\mathrm{C}(18)-\mathrm{N}(14)$ & $1.324(5)$ \\
\hline $\mathrm{N}(4)-\mathrm{C}(9)$ & $1.447(4)$ & $\mathrm{N}(14)-\mathrm{C}(19)$ & $1.466(4)$ \\
\hline $\mathrm{N}(4)-\mathrm{C}(1) 0$ & $1.456(4)$ & $N(14)-C(20)$ & $1.475(5)$ \\
\hline \multicolumn{4}{|l|}{ Angles } \\
\hline $\mathrm{N}(1)-\mathrm{Ni}(1)-\mathrm{N}(2)$ & $84.08(12)$ & $\mathrm{N}(1)-\mathrm{Ni}(1)-\mathrm{N}(13)$ & $92.94(12)$ \\
\hline $\mathrm{N}(2)-\mathrm{Ni}(1)-\mathrm{S}(1)$ & $85.57(9)$ & $\mathrm{N}(13)-\mathrm{Ni}(1)-\mathrm{S}(1)$ & $97.43(9)$ \\
\hline $\mathrm{N}(1)-\mathrm{Ni}(1)-\mathrm{S}(1)$ & $169.62(9)$ & $\mathrm{N}(13)-\mathrm{Ni}(1)-\mathrm{N}(2)$ & $176.20(12)$ \\
\hline $\mathrm{Ni}(1)-\mathrm{N}(1)-\mathrm{C}(2)$ & $113.3(2)$ & $\mathrm{Ni}(1)-\mathrm{N}(1)-\mathrm{C}(6)$ & $127.6(2)$ \\
\hline $\mathrm{Ni}(1)-\mathrm{N}(2)-\mathrm{C}(7)$ & $115.9(3)$ & $\mathrm{Ni}(1)-\mathrm{N}(13)-\mathrm{N}(12)$ & $129.1(2)$ \\
\hline $\mathrm{Ni}(1)-\mathrm{N}(2)-\mathrm{N}(3)$ & $125.9(2)$ & $\mathrm{Ni}(1)-\mathrm{N}(13)-\mathrm{C}(18)$ & $121.4(2)$ \\
\hline $\mathrm{Ni}(1)-\mathrm{S}(1)-\mathrm{C}(8)$ & $95.37(13)$ & & \\
\hline $\mathrm{N}(1)-\mathrm{C}(2)-\mathrm{C}(7)$ & $112.4(3)$ & $\mathrm{N}(1)-\mathrm{C}(6)-\mathrm{C}(17)$ & 119.7(3) \\
\hline $\mathrm{C}(2)-\mathrm{C}(7)-\mathrm{N}(2)$ & $114.2(3)$ & $\mathrm{C}(6)-\mathrm{C}(17)-\mathrm{N}(12)$ & $128.9(4)$ \\
\hline $\mathrm{C}(7)-\mathrm{N}(2)-\mathrm{N}(3)$ & $118.1(3)$ & $\mathrm{C}(17)-\mathrm{N}(12)-\mathrm{N}(13)$ & $121.6(3)$ \\
\hline $\mathrm{N}(2)-\mathrm{N}(3)-\mathrm{C}(8)$ & $109.9(3)$ & $\mathrm{N}(12)-\mathrm{N}(13)-\mathrm{C}(18)$ & $109.0(2)$ \\
\hline $\mathrm{N}(3)-\mathrm{C}(8)-\mathrm{N}(4)$ & $116.6(3)$ & $\mathrm{N}(13)-\mathrm{C}(18)-\mathrm{N}(14)$ & $114.0(3)$ \\
\hline $\mathrm{N}(3)-\mathrm{C}(8)-\mathrm{S}(1)$ & $123.2(3)$ & $\mathrm{N}(13)-\mathrm{C}(18)-\mathrm{S}(2)$ & $121.1(3)$ \\
\hline $\mathrm{N}(4)-\mathrm{C}(8)-\mathrm{S}(1)$ & $120.1(3)$ & $\mathrm{N}(14)-\mathrm{C}(18)-\mathrm{S}(2)$ & $124.9(3)$ \\
\hline $\mathrm{C}(8)-\mathrm{N}(4)-\mathrm{C}(9)$ & $122.8(3)$ & $\mathrm{C}(18)-\mathrm{N}(14)-\mathrm{C}(19)$ & $120.6(4)$ \\
\hline $\mathrm{C}(8)-\mathrm{N}(4)-\mathrm{C}(10)$ & $120.4(3)$ & $\mathrm{C}(18)-\mathrm{N}(14)-\mathrm{C}(20)$ & $123.0(3)$ \\
\hline
\end{tabular}

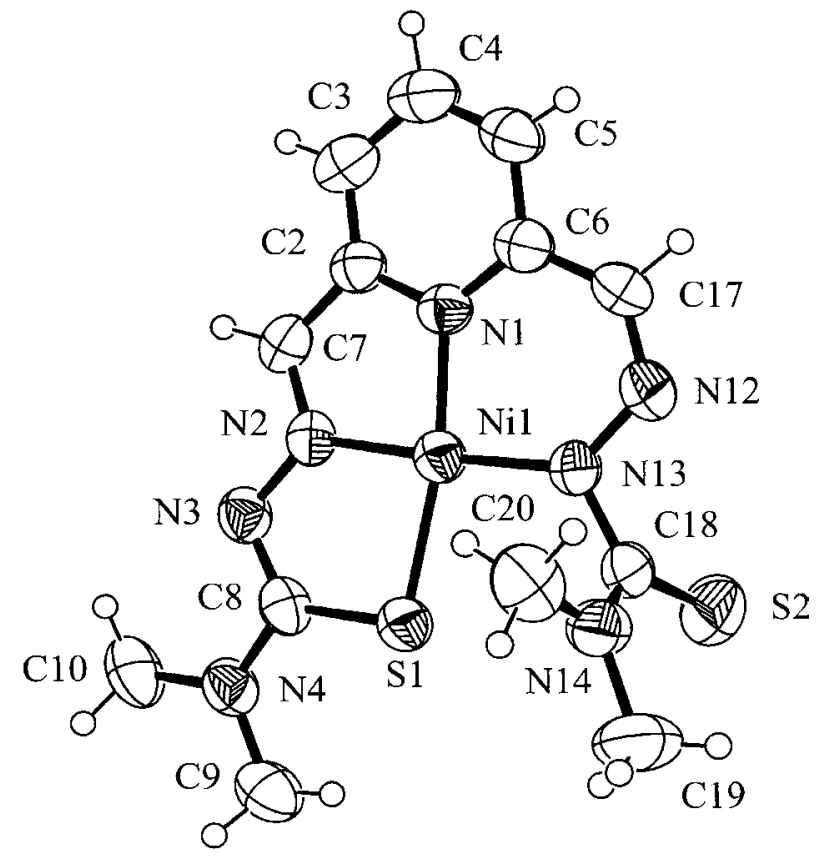

Figure 5. ORTEP drawing $(\mathrm{U}=0.050)$ of $[\mathrm{Ni}(2,6 \mathrm{Fo} 4 \mathrm{DM})]$ moieties coordinate in a different fashion; one is the typical coordination of a heterocyclic thiosemicarbazonato ligand, $\mathrm{N}$ (imine) nitrogen and thiolato sulfur atoms along with the pyridine nitrogen atom. The other thiosemicarbazone moiety coordinates via its hydrazinic nitrogen to make the complex 4-coordinate with a 5-5-6 trichelate system, rather than the expected 5-5-5 system. The nickel-ligand bond distances are as follows: $\mathrm{Ni}(1)-\mathrm{S}(1), 2.1827(9) \AA$; $\mathrm{Ni}(1)-\mathrm{N}(2), 1.849(3) \AA$; $\mathrm{Ni}(1)-\mathrm{N}(1), 1.876(3) \AA$ and Ni(1)$\mathrm{N}(13), 1.843(3) \AA$, and the "trans" bond angles are $176.20(12)^{\circ}$ for $\mathrm{N}(2)-\mathrm{Ni}(1)-\mathrm{N}(13)$, and $169.62(9)^{\mathrm{o}}$ for the bichelate ring $\mathrm{N}(1)-\mathrm{Ni}(1)-\mathrm{S}(1)$ indicating a planar nickel(II) center. A more complete list of selected bond distances and angles are shown in Table 5, which is arranged for convenient comparison of the thiosemicarbazone moieties. The four donor atoms, $\mathrm{S}(1)-\mathrm{N}(2)-\mathrm{N}(1)-\mathrm{N}(13)$, have a mean plane deviation of $0.0237 \AA$ with the nickel(II) center displaced slightly from this plane. The three chelate ring planes have even less deviation from planarity: $\mathrm{Ni}(1)-\mathrm{N}(2)-$ $\mathrm{N}(3)-\mathrm{C}(8)-\mathrm{S}(1)$ is $0.0113 \AA$, $\mathrm{Ni}(1)-\mathrm{N}(2)-\mathrm{C}(7)-\mathrm{C}(2)-\mathrm{N}(1)$ is $0.0118 \AA$ and $\mathrm{Ni}(1)-\mathrm{N}(1)-\mathrm{C}(6)-\mathrm{C}(17)-\mathrm{N}(12)-\mathrm{N}(13)$ is 0.0169 $\AA$ and the first two are essentially co-planar with each other, and $\mathrm{Ni}(1)-\mathrm{N}(1)-\mathrm{C}(6)-\mathrm{C}(17)-\mathrm{N}(12)-\mathrm{N}(13)$ is at an angle of $3.86(14)^{\circ}$ to the other chelate rings.

To our knowledge the only other nickel(II) species with similar bonding is a complex with 2,6-diacetylpyridine bis(S-methylisothiosemicarbazone), [Ni(H2,6AcSM $) \mathrm{I}],{ }^{48}$ which is described as pyramidal with a long $\mathrm{Ni}-\mathrm{I}$ bond distance, 3.485(2) ̊. The Ni(1)-N(2), Ni(1)-N(1) and Ni(1)$\mathrm{N}(3)$ bond distances, which are common to both complexes, are 1.844(2), 1.879(2) and 1.893(3) $\AA$; only the longer Ni(1)$\mathrm{N}(3)$ bond shows a significant difference. Coordination by $\mathrm{N}(3)$ instead of $\mathrm{N}(2)$ has also been found for the aldehyde thiosemicarbazone moiety of a planar palladium(II) complex of 1-phenylglyoxal bis\{N(4)-diethylthiosemicarbazone $\}$ to give a 5-6-4 trichelate system, ${ }^{11}$ and we recently have solved the nickel(II) complex of the same ligand with an identical bonding pattern. ${ }^{49}$

\section{Conclusion}

Coordination of heterocyclic bis(thiosemicarbazones) as neutral, monoanionic and dianionic ligands is possible depending on the metal center and the particular metal salt selected for complex preparation. To date, these ligands have been shown to coordinate as planar pentadentate and tetradentate ligands to one metal center or bridging ligands in binuclear complexes. Further structural studies of complexes of these ligands will likely expand the field with new modes of coordination. Substitution on the pyridine ring, as well as more complexes with substituted 
thiosemicarbazone moieties will help to achieve these new modes of coordination.

\section{Supplementary material}

Crystallographic data for the structure reported in this paper (excluding structure factors) have been deposited with the Cambridge Crystallographic Data Center as Supplementary Publication No. CCDC-164068. Copies of the data can be obtained free of charge on application to CCDC, 12 Union Road, Cambridge CB2 1EZ, UK (Fax: + 44-1223/336-033. E-mail: deposit@ccdc.cam.ac.uk).

\section{References}

1. Ali M. A.; Livingston, S. E.; Coord. Chem. Rev. 1974, 13, 101.

2. Campbell, M. J. M.; Coord. Chem. Rev. 1975, 15, 279.

3. Padhye, S. B.; Kauffman, G. B.; Coord. Chem. Rev. 1985, 63, 127.

4. West, D. X.; Padhye S. B.; Sonawane, P. B.; Struct. Bonding, 1991, 76, 1.

5. West, D. X.; Liberta, A. E.; Padhye, S. B.; Chitake, R. C.; Sonawane, P. B.; Kumbhar A. S.; Yerande, R. G.; Coord. Chem. Rev. 1993, 123, 49.

6. Swearingen, J. K.; West, D. X.; Transition Met. Chem. 2001, 26, 252 and references therein.

7. West, D. X.; Ives, J. S.; Bain, G. A.; Liberta, A. E.; ValdésMartínez, J.; Ebert, K. H.; Hernández-Ortega, S.; Polyhedron 1997, 16, 1895.

8. Beraldo H.; West, D. X.; Transition Met. Chem. 1997, 22, 294.

9. Beraldo, H.; Ives, J. S.; Kaisner, S. B.; Turner, J. D.; Billeh, I. S.; West, D. X.; Transition Met. Chem. 1997, 22, 459.

10. Beraldo, H.; Boyd, L. P.; West, D. X.; Transition Met. Chem. 1998, 23, 67.

11. Castiñeiras, A.; Bermejo, E.; West, D. X.; El-Sawaf, A. K.; Swearingen, J. K.; Polyhedron 1998, 17, 2751.

12. Castiñeiras, A.; Bermejo, E.; Ackerman, L. J.; Beraldo, H.; West, D. X.; J. Mol. Struct. 1999, 477, 1.

13. Castiñeiras, A.; Bermejo, E.; West, D. X.; Ackerman, L. J.; Valdés-Martínez, J.; Hernández-Ortega, S.; Polyhedron 1999, 18,1463

14. Ackerman, L. J.; Webb, J. W.; West, D. X.; Transition Met. Chem. 1999, 24, 562.

15. Ackerman, L. J.; Fanwick, P. E.; Green, M. A.; John, E.; Running, W. E.; Swearingen, J. K.; Webb J. W.; West, D. X.; Polyhedron 1999, 18, 2759.

16. Durán, M. L.; Sousa, A.; Romero, J.; Castiñeiras, A.; Bermejo E.; West, D. X.; Inorg. Chim. Acta 1999, 294, 79.

17. Castiñeiras, A.; Bermejo, E.; Ackerman, L. J.; Beraldo, H.; Valdés-Martínez, J.; Hernández-Ortega, S.; West, D. X.; $J$. Mol. Struct. 1999, 510, 157.
18. Gil, M.; Bermejo, E.; Castiñeiras, A.; Beraldo H.; West, D. X.; Z. Anorg. Allg. Chem. 2000, 626, 2353.

19. Bermejo, E.; Gil, M.; Castiñeiras, A.; Labisbal, E.; Sousa, A.; Beraldo H.; West, D. X.; Z. Naturforsch. 2000, B55, 863.

20. Castiñeiras, A.; Gil, M.; Bermejo, E.; West, D. X.; Polyhedron 2001, 20, 449.

21. Castiñeiras, A.; Gil, M.; Bermejo, E.; West, D. X.; Z. Anorg. Allg. Chem., in press.

22. Ackerman, L. J.; West, D. X.; Mathias, C. J.; Green, M. A.; Nuclear Medicine and Biology 1999, 26, 551.

23. Mohan, M.; Agarawal, A.; Jha, N. K.; J. Inorg. Biochem. 1998, $34,41$.

24. Maji, M.; Ghosh, S.; Chattopadhyay, S. K.; Transition Met. Chem. 1998, 23, 81.

25. Hall, I. H.; Lackey, C. B.; Kistler, T. D.; Ives, J. S.; Beraldo, H.; Ackerman L. J.; West, D. H.; Arch. Pharm. Pharm. Med. Chem. 2000, 333, 217.

26. de Sousa, G. F.; West, D. X.; Brown, C. A.; Swearingen, J. K.; Valdés-Martínez, J.; Toscano, R. A.; Hernández-Ortega, S.; Hörner M.; Bortoluzzi, A. J.; Polyhedron 2000, 19, 841.

27. West, D. X.; Bain, G. A.; Butcher, R. J.; Jasinski, J. P.; Li, Y.; Pozdniakiv, R. Y.; Valdés-Martínez, J.; Toscano R. A.; Hernández-Ortega, S.; Polyhedron 1996, 15, 665.

28. Valdés-Martínez, J.; Hernández-Ortega, S.; West, D. X.; Ives J. S.; Bain, G. A.; Z. Krystallogr. 1998, 213, 246.

29. Castiñeiras, A.; Garcia, I; Bermejo, E.; Ketcham, K. A.; ElSawaf, A. K. West, D. X.; Polyhedron, in press.

30. Dessy, G.; Fares, V.; Cryst. Struct. Commun. 1981, 10, 1025.

31. Mohan, M.; Sharma, P.; Kumar, M.; Jha, N. K.; Inorg. Chim. Acta 1986, 125, 9.

32. Carcelli, M.; Ianelli, S.; Pelagatti, P.; Pelizzi, G.; Inorg. Chim. Acta 1999, 292, 121.

33. Abram, S.; Maichle-Mössmer, C.; Abram, U.; Polyhedron 1998, $17,131$.

34. Timkin, M. D.; Wilson, S. R.; Hendrickson, D. N.; Inorg. Chem. 1985, 24, 3450.

35. Sonawane, P.; Chikate, R.; Kumbhar, A.; Padhye, S.; Polyhedron 1994, 13395.

36. Kovala-Demertzi, D.; Domopoulou, A.; Demertzis, M.A.; Valdés-Martínez, J.; Hernández-Ortega, S.; Espinosa-Pérez, G.; West, D. X.; Salberg, M. M.; Bain, G. A.; Bloom. P. D.; Polyhedron 1996, 15, 2587; Bermejo, E.; Castiñeiras, A.; Ackerman, L. J.; Owens, M. D.; West, D. X.; Z. Allg. Anorg. Chem., submitted.

37. Casas, J. S.; Castiñeiras, A.; Sanchez, A.; Sordo, J.; VazquezLopes, A.; Rodriguez-Aguelles, M. C.; Russo, U.; Inorg. Chim. Acta 1994, 221, 61.

38. de Sousa, G. F.; Filgueiras, C. A. L.; Abras, A.; Hitchcock, S. S.; Nixon, J. F.; Inorg. Chim. Acta 1994, 218, 139.

39. Moreno, P. C.; Francisco, R. H. P.; Gambardella, M. T. D. P.; De Sousa, G. F.; Abras, A.; Acta Cryst. 1997, C53, 1411. 
40. Battaglia, L. P.; Bonamartini Corradi, A.; Pelizzi, C.; Pelosi, G.; Tarasconi, P.; J. Chem. Soc., Dalton Trans. 1990, 3857.

41. Valencia, L.; Adams, H.; Bastida, R.; de Blas, A.; Fenton, D. E.; Macias, A.; Rodriguez, A.; Rodriguez-Blas, T.; Inorg. Chim. Acta 2000, 300, 234.

42. Bino, A.; Cohen, N.; Inorg. Chim. Acta 1993, 210, 11.

43. Rodriguez-Argüelles, M. C.; Ferrari, M. B.; Fava, G. G.; Pelizzi, C.; Tarasconi, P.; Albertini, R.; Dall' Aglio, P. P.; Lunghi, P.; Pinelli, S.; J. Inorg. Biochem. 1995, 58, 157.

44. Labisbal, E.; Castiñeiras, A.; Brown, C. A.; West, D. X.; Z. Naturforsch 2001, 56b, 229.

45. Wassmaier, D.; Kirfel, A.; Acta Cryst. 1995, A51, 416.
46. Mackay, S.; Edwards, C.; Henderson, A.; Gilmore, C.; Stewart, N.; Shankland, K.: Donald, A.; MAXUS, version 2; University of Glascow, Scotland; 1997.

47. Spek, A. L.; PLATON. A Multipurpose Crystallographic Tool; Utrecht University, Utrecht, The Netherlands; 1999.

48. Leovac, V. M.; Bogdanovic, G. A.; Cešljevic, V. I.; Divjakovic, V.; Acta Cryst. 2000, C56, 936.

49. Bermejo, E., Castiñeiras, A., Ackerman, L. J. Owens, M. D., West, D. X.; Z. Allg. Anorg. Chem. 2001, 6271966.

Received: June 8, 2001 Published on the web: December 5, 2001 